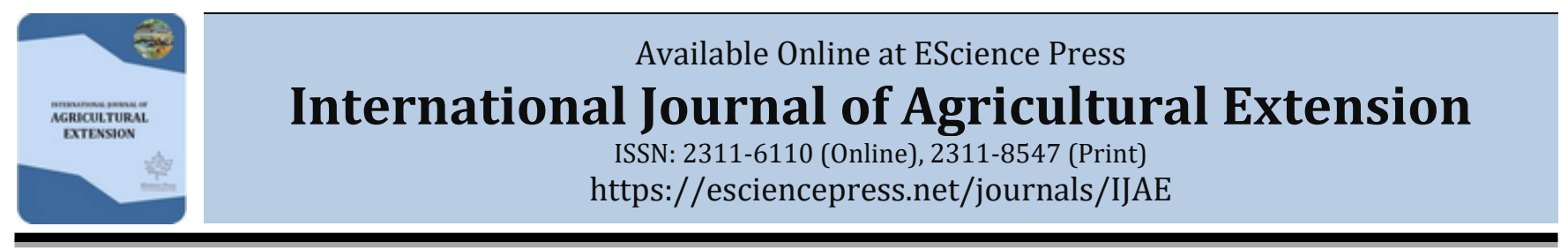

\title{
PARTICIPATORY IMPROVED POTATO TECHNOLOGY PROMOTION: THE CASE OF SMALLHOLDER FARMERS IN NORTH, WEST AND SOUTHWESTERN HIGHLANDS OF ETHIOPIA
}

\author{
Abebe C. Degebasa \\ Ethiopian Institute of Agricultural Research/EIAR/, Holetta Agricultural Research Center/HARC/, Horticulture Research \\ Division, Addis Ababa, Ethiopia.
}

*Corresponding Author Email: abechindii@yahoo.com

\begin{abstract}
A B S T R A C T
Utilization of healthy planting material is a key factor to improve potato yields to reduce the dissemination of diseases and pests. Quality seed is one of the major bottlenecks hindering the production and productivity of potato in major potato growing regions of the country. Therefore, participatory on-farm seed production and improved potato technologies promotion have been carried out during the year 2014-2016 at five districts, Jeldu, Dendi, Wolmera Degem and Kersana Malima of central Ethiopia. To produce quality potato seed various rapid multiplication techniques were used. Thus, improved potato technologies were demonstrated using different methodologies such as the farmers' field schools, the farmers' research group and field days. To supply clean tubers about 138,886 highquality mini-tubers of improved varieties of Belete, Gudanie, Jalenie and Awash were produced. Moreover, a total of 257.08 tons of seed tubers of 15 released potato varieties were produced and disseminated in different parts of the country for research and developments. The participant farmers produce 442.9 tons of relatively clean seed tubers and sold to different parts of the country. During, this activity positive selection technique was demonstrated and participant farmers applied the techniques that helped them to improve the yield and quality of seed potato. Farmers obtained a $40 \%$ yield increase and a 33\% vigour improvement when positive selection techniques were applied. Training on improved potato production and postharvest handling technologies have also been given for farmers, development agents, agricultural experts and home agents. Therefore, decentralized quality seed production reduces the movement of dangerous diseases like bacterial wilt and viruses from invading areas with high potential for seed production due to purchase of seed only from within one's same region.
\end{abstract}

Keywords: Potato, Informal Seed Production, Mini-tubers, Positive Selection, RMT, FFS \&FRG.

\section{INTRODUCTION}

Potato (Solanum tuberosum L.) is a high potential food security crop in Ethiopia due to its high yield potential and nutritional quality tuber, short growing period, and wider adaptability (Tewodros et al., 2014). It is one of the main sources of food in several regions of the world, and its cultivation has been increasing particularly in developing countries and tropical countries (FAOSTAT, 2014). Potato production in Ethiopia is more concentrated in Northwest, Central highlands, South and Southeast and Eastern parts of the country with rural districts but production is as low as 10 tons ha- ${ }^{-1}$ (Haverkort et al., 2012). Studies conducted by Gebremedhin et al. (2008) and Hirpa (2010) revealed that the potential average potato tuber yield in Ethiopia is 25-45 tons ha $^{-1}$ under optimal agronomic practices. Moreover, shortage or lack of high yielding, sufficient quantity of good quality seed of potatoes is one of the most important constraints that limit both production and productivity of potato. In most areas of Ethiopia, among local farmers, it is a common practice to save the small and inferior tubers as seed that they cannot normally sell for consumption. It is believed that this practice has contributed to the build-up of high level of virus diseases in the locally grown potato cultivars in Ethiopia (Gebremedhin et al., 2008). In vegetatively propagated crops, reusing planting material over successive generations causes build-up of seed 
pathogens resulting in losses due to seed degeneration (Rahman et al., 2010). In Ethiopia, potato production increased considerably through the 20th century. In 1975 , the area of cultivation was estimated at 30,000 ha, with an average yield of approximately 5tons ha-1. By 2001, Ethiopia's potato area had grown to 160,000 ha, with average yields of around 8 tons ha-1 (Gebremedhin et al., 2001) and by 2014 the potato area had grown to 179,159 ha with average yields of around 10 tons ha-1 (CSA, 2014). Potato can still grow on $70 \%$ of the 10 million ha of arable land in the country (FAOSTAT, 2008). Low yields of potato in the tropics are attributed to a multitude of factors including, late blight (Phytophthora infestans), bacterial wilt (Ralstonia solanacearum E. M. smith) and limited availability of improved seed are the major constraints to successful potato cultivation (Sengooba et al., 2001). It was also reported that repeated use of the same seed stock infested with different diseases has resulted in devastating disease epidemics, drastically reducing yields (Low, 1997). Shortage or lack of healthy, high yielding planting materials and the common practice among farmers of planting undersized potato tubers are some of the major limiting factors to production of potatoes in Ethiopia. Consequently, yields have remained persistently below 8 ton ha-1 in comparison to over 35 tons ha-1 attainable under research condition and over 25 tons ha-1 on farmers' fields using the improved potato technologies (Gebrmedhin et al., 2008), despite the area under potato cultivation having expanded almost four-fold from 30,000 ha in to 160,000 ha in 2001(Gebremdhin et al., 2001) the yield was stagnant. Moreover, the potato area had grown to 296,000 ha with average yields of 12.36 tons ha-1 (CSA, 2015/16) in the same trend the average yields of the country grew up to 14 tons ha ${ }^{-1}(C S A, 2019 / 20)$. The quality seed of an improved potato variety is a key to increase the productivity of a potato crop. The genetic potential and other traits of a potato variety are determined or manifested by the use of healthy seed (Endale et al., 2008).

Among potato production problems, a major bottleneck that contributes to low yield in Ethiopia is the lack of healthy and quality seed tubers in the required quantity and quality (Berga \& Gebremedhin, 1994). There is no formal seed system operating for clean/healthy potato seed multiplication and distribution in Ethiopia. Hirpa et al. (2010) reported that potato seed production in
Ethiopia is basically informal, which in most cases operates by recycling planting materials from previous crop harvest.

Absence of seed certification system and certified seed tubers is a major constraint to potato production in Ethiopia. As a factor of seed shortage farmers commonly plants tubers obtained by saving from a previous seasons' crop or by purchasing from neighbours or market places. However, such tubers have a high potential of harbouring tuber-borne diseases such as bacterial wilt and those caused by viruses. Thus, planting of disease-free seed tubers has been recognized as a very important aspect in boosting potato yields and controlling diseases, other components of integrated management can then be applied more reliably and effectively. Holetta Agricultural Research Center (HARC) has the national mandate to produce basic seed tubers (Breeder's seed) but can only supply few starter seeds for the national requirements due to several reasons. In many African countries including Ethiopia efforts are undergoing to strengthening seed production programs. The use of informal or participatory seed tuber production has been implemented in the last few years in collaboration with the international potato centre (CIP) and Regional Potato and Sweet Potato Improvement Program in Eastern and Central Africa (PRAPACE). Therefore, this system has been seen as best alternative in developing countries where there are no formal seed systems.

To minimize this challenge, from 2014-2016 Holetta Agricultural Research centre (HARC) began promoting improved potato technologies and the adoption of positive selection (PS) and farmers practices (FP) in the central highlands of Ethiopia where potato is a major food security and cash crop in the country. The potato team of HARC has been offering technical support and encouraging smallholder farmers who can produce seed on their own to adopt and demonstrate quality seed in potato production through FFS using PS. In a participatory approach with farmers, trials comparing seed generated from positive selection and seed obtained through farmers' practices were demonstrated. Potato is the major food and cash crop after barley in West Shewa and North Shewa Zones. The farmers in this area are the source of seed potatoes for most parts of the country (Gildemacher et al., 2009). In the process, the tubers become infested with potato tuber moth, red ants and other soil born potato diseases as well as wild 
animals. As a result the tubers will not be in their optimum health and physiological stage for planting. This results in to poor establishment and eventually very poor growth and yield; thus, the use of improved varieties, improved production technologies and diffused light store should be demonstrated to the farmers (Gildemacher et al., 2011).

The main challenge of the informal seed potato production system in most African countries is suggested to be a lack of rigorous seed health testing and certification (Sengooba et al., 2001). This makes it difficult to sustain distribution of healthy seed tubers to farmers. As a way of increasing the availability of satisfactory healthy seed tubers to poor small-scale farmers, a participatory seed potato tuber production was started in the central highlands of Ethiopia (Wolmera, Jeldu, Kersana Malima, Dendi and Degem) districts.

\section{Objectives:}

- To evaluate the improved potato seed production technologies on a farmer's field.

- To determine the efficiency of positive selection technique against farmers practice in improving the quality of potato planting material.

- To train farmers on the production of clean and healthy seed potatoes in a sustainable manner.

- To gain experience on farmer-based seed potato production system in the intervention districts.

\section{RESEARCH METHODOLOGY}

\section{On station seed production}

Meristem culture: Meristem culture is one of the important plant tissue culture applications for the elimination of viruses from planting materials (Naik \& Karihaloo, 2008; Badoni \& Chauhan, 2010). It is a procedure in which apical/axillary growing tip (0.1 to $0.3 \mathrm{~mm}$ ) are dissected and allowed to grow into plantlets on artificial nutrient media under controlled conditions. This technique for virus elimination is based on the principle that, many viruses are unable to infect the apical/axillary meristems of a growing plant and that a virus-free plant can be produced if a small piece meristem is propagated (Kassanis, 2008). Tissue culture is not limited by time of the year or weather (Batool et al., 2014). In addition, conditions in the laboratory are ideal and therefore, conducive to all year round production scheduling. It also saves an enormous amount of daily care required by convectional cuttings and seedlings (Mahamond, 2006). Tissue culture is also used in somatic hybridization, the induction and selection of mutants and biosynthesis of secondary products. Most developing countries fail to maximize tissue culture technology due to high operational costs involved as it requires specialized equipment which is very expensive to acquire. In addition, different nutrients, energy sources, vitamins and growth regulators used for media formulation are also very expensive (Badoni \& Chauhan, 2010).

Multiplication and Distribution of Healthy Potato Planting Materials: The supply of healthy planting material is of prime importance in promoting potato production in Ethiopia. The ultimate availability of adequate planting material of desired varieties has been one major drawback in production (FAO, 2010). As potato is fast becoming of high value for household consumption and income generation, its cultivation is gaining more attention. However, dissemination of improved potato technologies and information is a critical aspect of the promotion of potato. Technology transfer has, become the key component of the potato project at Holetta research in the last six to eight years.

The Holetta research aims at increasing and improving the production of potato in Ethiopia through promoting the use of planting material of superior performance. Pathogen free planting material of selected varieties is multiplied at Holetta and Jeldu and distributed to growers in selected districts of the country. The selection of the districts is based mainly due to their potential to grow healthy seed tubers and proximity to the research.

Participatory informal seed production: Production of potato in Ethiopia: In Ethiopia, the potato is grown in four major areas: the central, the eastern, the northwestern and the southern. Together, they cover approximately $83 \%$ of the potato farmers (Hirpa et al., 2010; CSA, 2009). In the central area, potato production includes the highland areas surrounding the capital, i.e. Addis Ababa, within a $100-150 \mathrm{~km}$ radius. In this area, the major potato growing zones are West Shewa and North Shewa. About $10 \%$ of the potato farmers are located in this area (CSA, 2009). The average productivity of a potato crop ranges from 8 to 10 ton $\mathrm{ha}^{-1}$ which is higher than the productivity in the Western and southern areas. The higher productivity might be due to the use of improved varieties and practices obtained from Holleta Agricultural Research Centre in the central area. In the central area, the potato is 
produced mainly in the Belg (short rain season February to May) and Meher (long rain season from June to October) periods. Potato is also grown during off-season under irrigation (October to May). Because of the cool climate and access to improved varieties, farmers in this area also produce seed potatoes which are sold to other farmers in the vicinity or to NGOs and agricultural bureaus to be disseminated to distant farmers.

Participatory potato technology development and dissemination were undertaken in the central highlands of Ethiopia. The method used to address the constraints of potato production and to disseminate the available technologies was informal seed production through a farmers' participatory approach encompassing FFS, training, and field days. These activities were aimed at increasing awareness of the benefits of improved seed potato quality management and crop husbandry. Moreover, the aim was to help farmers to access potato technologies at an affordable price and to train farmers in the sustainable production of clean and healthy seed potatoes, post-harvest management and utilization. The community based seed production was carried out at Wolmera, Dendi, Jeldu, Degem and Kersana Malima districts. To disseminate the improved technologies of potato seed tuber production, Farmer Field Schools /FFS/ and Farmer Research Groups /FRG/ organized for the activities on Integrated Disease Management (IDM), Integrated Nutrient Management (INM) and Postharvest handling $(\mathrm{PHH})$ were used for the implementation of the activity. Each FFS is constituted from an average of 25 members with 20 male headed and 5 female headed household and each FRG had five members. On the other hand, follow-ups have been made to other potato producing farmers in the respective districts to monitor their field for cleanness from pests, diseases and offtypes. Improved potato varieties released by HARC have been used for the activity. Apart from the ones delivered by Holetta research other farmers have managed to obtain the seeds from neighbouring farmers through sales and seed exchange. All the agronomic practices have been carried out as per the recommendation of HARC for potato production. Planting was conducted during early June during all the three years for the demonstration activities. Recommended rates of inorganic fertilizer were used at $195 \mathrm{~kg} \mathrm{ha}^{-1}$ and $165 \mathrm{~kg}$ ha $^{-1}$ of DAP and Urea, respectively, and side dressed at time of planting. A supplementary single spray of Ridomil Gold against late blight was practiced in each location at a rate of $2 \mathrm{~kg}$ per ha-1 (Berga et al., 1994).

Positive selection: Positive selection methods are used primarily in informal seed potato multiplication to select a disease-free mother plant as a starting point (Salazar, 1996). Positive selection (PS) involves the identification and marking of healthy-looking plants for seed generation. The positive selection activity was implemented on formerly established six FFSs at Jeldu and Dendi districts. The experiment has been implemented from 2014 to 2016 at three locations in Jeldu district using improved varieties which are being multiplied by farmers. In 2014 initial stock has been selected from the farmer stock and was stored separately to be used for the experiment for the next season. The experiment has been laid out in RCB design in three replications at each site. A plot size of $3.75 \mathrm{~m} \mathrm{x}$ $4.8 \mathrm{~m}$ was used to accommodate 80 plants per plot. All the agronomic practices were conducted as per the recommendation. Positive selection was conducted using wooden pegs to mark vigorous and healthylooking plants just before flowering, and these plants were harvested and stored separately to be used again for the next season.

Management of the potato field was carried out by participant farmers, and they have cultivated the crop twice during the growing period (20 days after emergence and just before canopy closure). Two field sessions have been organized in a growing season; one on importance of the activity and selection procedures and the second on harvest considerations in implementing the activity. The training was given on selection techniques of elite materials at field level for disease-free seed, optimum tuber size and construction and the use of Diffused Light Store (DLS) to ensure improved and quality seed tuber production at farmer's level. Participant farmers were advised to retain the potato seed tubers for the next planting season in the diffused light storage (DLS) they constructed. Therefore, Geldmacher et al. (2011) reported that the practice of positive selection can easily improve the quality of seed in farmers' field. The technique and procedure are simple and can easily be transferred to subsistence potato farmers through farmer field school. The relative efficiency of this technique in improving seed quality has not been evaluated in the study areas before 2014 .

Training: Intensive and extensive training was organized for potato producer farmers, development agents (DA), agricultural extension experts of MoARD 
and NGO in Oromia, Amhara, Tigray, and SNNP regional states which focused on clean seed potato production and handling, postharvest management of ware and seed potatoes and different recipe preparation from potato. These trainings have also been given to FFS participants on integrated disease management (IDM), integrated nutrient management (INM) and postharvest handling. The basic methods used for the training were both onstation and hands-on on-farm approached based on the situation and convenience. Rigorous discussions have also been made with the trainees regarding the subject in question. To effectively convey the information various demonstrations and visiting have been organized in all the three years during 2014-2016.

Achievements in participatory Improved Technology Promotion

The Multiplication and Distribution Scheme: In Ethiopia as a whole, more than 35 potato varieties with their full package were formally released for production for wider adaptation (MoA, 2018). However, these varieties and their technological packages were not fully promoted. During this activity, quality planting materials which are multiplied at Holetta on-station are distributed for participant farmers and different research for seed production or research purposes. A total of 257.08 tons of seed potatoes of fifteen released potato varieties have been produced on-station at Holetta and Jeldu from 2014-2016 were distributed. The distribution of the materials to farmers was using farmer groups organized into farmer field schools (FFS) or farmer research groups (FRG).

Table 1. Number of mini tubers produced under screen house at HARC in 2014-16.

\begin{tabular}{lcccc}
\hline Variety & \multicolumn{4}{c}{ Year of productions } \\
\cline { 2 - 5 } & 2014 & 2015 & 2016 & Total \\
\hline Dagim & - & - & 3,000 & 3,000 \\
Belete & 38,390 & 67,078 & 10,947 & 116,415 \\
Gudenie & 864 & 1,278 & 3,300 & 5,442 \\
Awash & 4,659 & - & - & 4,659 \\
Jalenie & 233 & 2,362 & 6775 & 9,370 \\
Total & 44,146 & 70,718 & 24,022 & 138,886 \\
\hline
\end{tabular}

This had led the foundation of reaching more farmers at a place and time. The healthy planting materials/stocks multiplied using rapid multiplication technique /RMTs are of the selected varieties which are maintained under strict hygienic conditions in an insect-proof screen house. Subsequent propagation is carried out using in vitro plantlets in the screen house to obtain enough planting material before they are planted in open field. By using this technique it was possible to produce 138,886 mini-tubers during the three years (Table 1). These materials have been induced the seed production program and have played a paramount role in regenerating the materials at hand.

Participatory seed production: Established Farmers field school (FFS) and Farmer's research group (FRG): For participatory seed potato production FFS and FRG were organized based on the request from districts BoA to access quality planting materials and technology popularization. Thus, only farmers who were willing to be involved in the Farmers' Field School (FFS) and Farmer Research Group (FRG) were selected. Farmers were encouraged to allocate their plots necessary for the trials and conduct seed production. Member farmers fully participated in the management of the trials: planting, fertilization, weeding, and cultivation, which were done according to research recommendations. Both farmers and researchers followed up the trials and researchers made periodic observations. In general, selection was made using the earlier set criteria, including willingness of the farmer to be a potato seed grower, willingness to work in a group, and capacity to build DLS for seed storage. Based on these criteria, 2025 farmers were selected per site in the first season (2014) for FFS and 12-15 farmers for FRG where five of them are female house head. Selection and organization of FFS and FRG continued in the following seasons using the same procedure, but more than one group of FFS per site.

Many farmers were willing to participate in such activities after observing the performance of the improved potato varieties under rainfed conditions and the benefits of participant farmers. A total of 1712 farmers participated from both FFS and FRG from Oromia regional states were trained on clean potato seed production and postharvest management. In general, organized farmers got additional training on potato late blight (LB) management, seed and ware potato production, and storage technologies in workshops and discussions. These groups were getting strong technical backup of researchers and extension agents of Bureau of Agriculture at local level throughout the project period. Therefore, about six different improved potato varieties were demonstrated and popularized in three districts and a total of 442.9 tons of relatively quality seed potato produced over period of 
three years by participant farmer groups.

Positive selection activity: A total of six FFS were selected to undertake the positive selection training and the experiment was undertaken on three FFS fields. A total of 140 farmers have been trained on the practice from the six farmer field schools. Therefore, the practice of positive selection was implemented using framers' seed stock, which was retained from the previous year's potato harvest.

In order to implement the training effectively, two field sessions were organized by facilitators and their guides were prepared. Thus, first session was on positive selection procedures and was given when the crop was at its early flowering stage. The second session was on considerations during harvesting management of tubers and this session was given during harvesting. In the sessions given participant farmers were taught on the importance of positive selection activity and its benefits in improving the seed stock quality.

In addition to the 140 participant farmers, the district office of MoARD has invited more than 200 farmers to participate on the field day, which was organized by HARC at Jeldu district. In the experiment conducted, a significant difference has been observed in yield, Average Tuber Weight (ATW) and plant vigour between positive selection and farmers practices. Yield advantage of $39.5 \%$ has been obtained in adopting positive selection technique and a $22.6 \%$ increment has been obtained in ATW in the positively selected treatment over the farmer practice. Plant height was not significant, but plant vigour was significant, and a $33 \%$ advantage was obtained in adopting positive selection practice

(Table

2).

Table 2. Summary results of the positive selection experiment conducted at Jeldu district (2015 - 2016).

\begin{tabular}{lcccc}
\hline Treatments & Yield $(\mathrm{t} / \mathrm{ha})$ & ATW $(\mathrm{g})$ & Plant height $(\mathrm{cm})$ & Plant Vigor $\left(1-5^{*}\right)$ \\
\hline Positive selection & $60.09 \mathrm{~A}$ & $95.47 \mathrm{~A}$ & $60.98 \mathrm{~A}$ & $4 \mathrm{~A}$ \\
Farmers practice & $43.06 \mathrm{~B}$ & $77.88 \mathrm{~B}$ & $60.88 \mathrm{~A}$ & $3 \mathrm{~B}$ \\
CV (\%) & 27.6 & 24.54 & 33.9 & 26.6 \\
\hline
\end{tabular}

Means within a column followed by the same letters are not significantly different at the prescribed level of significance. $* 1$ least vigour and 5 vigorous.

Training and Demonstrations: As a component of technology promotion, training was provided for FFS group members in three districts on potato production, disease and insect pest protection and postharvest management techniques before the distribution of planting material. Since the inception of this activity, training has been offered for 1712 farmers in Oromia regional states which emphasize on potato production and postharvest management techniques. The main aims of the training workshops were to increase and improve potato production through capacity building by imparting appropriate knowledge and skills. Trainees for this activity include farmers, development agents from extension department of MoARD, technicians and extension workers from NGOs. Training is conducted through lectures, discussions, field sessions and field days. Participants are provided with important production guides and notes to complement the training. In most cases farmers were organized into groups either farmer field schools (FFS) or farmers research group (FRG) in order to be effective and address more farmers. Demonstrations of improved agronomic practices are organized on field days for the selection and evaluations of new varieties. This will facilitate information exchange and distribution of materials among the endusers. Scientific results and recommendations on the production of potato are relayed to non-institutional members through local publications viz. pamphlets, leaflets, fliers and production guide. Through these approaches a vast number of farmers have benefited from the information provided. Training of farmers on the use of healthy seed tubers and other aspects of integrated disease management, to incorporate field sanitation/hygiene, is an important consideration if the informal potato seed production is to realize its potential impact of increasing the availability of disease-free seed tubers.

Discussion and Conclusions: The first ideas about participatory research (PR) in agriculture were initiated about three decades ago. Participatory methods for diagnosing farmer problems is a method oriented to involving farmers in different steps of technology development up to final decisions of technologies to scale out. The dissemination of potato production 
technologies through demonstration started in the early 1990s in Wolmera district of West Shewa Zone. Since then, the demonstration program has continued and expanded to cover other major potato growing areas in the zone and beyond. Lack of sustainable seed potato production system has been a major problem in the diffusion of improved potato varieties and expansion of potato production in Ethiopia. There is no government or private agency, which produces and distributes seed potatoes in the country. Therefore, farmers resort to the available local varieties which are susceptible to late blight and produce very low yield as the degeneration, modified planting time, etc. Potato seed transported from long distance is very expensive, requires intensive management and it may not reach an optimum physiological condition at the destination. In the absence of seed potatoes producing company, an informal and community-based seed potato production system is an alternative. The system enables farmers get appropriate improved varieties, relatively healthier and sound seed potatoes than the local varieties and seed at an appropriate physiological age for planting. Moreover, it enables farmers build diffused light store (DLS) for the storage of seed potato tubers. The system could also serve as a means of disseminating improved potato technologies to farmers. Beside demonstration efforts, dissemination of information using different outlets has created some level of awareness on the side of potato growers on available improved production technologies. These include farmers' field days, distribution of pamphlets, training of farmers and subject matter specialists, and use of different mass media. The creation of awareness has been demonstrated by the multitude of growers and development agents, both from GOs and NGOs, who have been coming from far away from places to West Shewa seeking for seed tubers of improved potato varieties from successful potato tuber seed growers. Specific joint projects namely CIP, PRAPACE, IFAD-FFS-Ethiopia and AHI coordinated by EIAR have also contributed considerably for potato technologies transfer efforts to farmers. Moreover, farmer to farmer improved potato tuber seed and information exchange has played key role in the dissemination of improved potato production technologies. From this activity, it can be concluded that informal seed tuber production on the farmers' field contributed to producing healthy seed tuber. The demand for quality seed increased exponentially due to successive training and yield increment. Moreover, during the intervention, the participant farmers got skill and knowledge on principle of quality seed production \& crop husbandry to get better yield as compared to traditional practices. The FFS group members understood use of fungicides as soon as the symptoms of late blight disease appear and also use of postharvest handling technology for storing seed potato tubers (DLS) for 8-9 months were appreciated and adopted very well. Thus, in addition to seed tuber production going on in the research stations, informal seed production in the farmers' fields has now become a major practice which helps the farmers to get relatively clean and sufficient seed for the next cropping season and also benefit from selling to other users.

The system enabled farmers to get improved varieties, relatively healthier and sound seed potatoes than the local varieties and seed at an appropriate physiological age of planting. Therefore, the improvement in the practices to produce better quality seed potato in the central area of Ethiopia is achieved because of the concerted efforts of the Ethiopia Institute of Agricultural Research (EIAR). Holetta Agricultural Research Centre of the EIAR has been assisting farmers in the central area of Ethiopia in providing seed and training through its farmers' field school (FFS) and farmers' research group.

Recommendations: Increasing the production and productivity of potato crop is an important factor in ensuring food and nutrition security, and livelihood and health improvement of the nation. In addition, the export potential for potato is enormous, which shows the possible contribution of the sector for the country's aspired economic growth and poverty reduction agenda. Therefore, the following recommendations could drown which have a pivotal role in quality seed tuber production effort that would help the producers' farmers to be engaged in potato seed business. Strengthening and expanding the capacity of the research centre for multiplication of early generation seed (EGS) and distribution of quality planting material.

- Establishment of more community owned potato producing FFS and FRG that will be promoted to more functional seed producers' cooperatives.

- Increased farmer knowledge of potato seed production and management

- Introduction and dissemination of new suitable improved potato varieties for the specific localities.

- Strengthening the postharvest technologies of potato for sustainable seed tuber production. 
- Strengthening the training program for farmers, development agents, subject matter specialists and regular periodic technical backstopping to producers.

- Establishing seed certification scheme for sustainable seed potato tuber in the country.

Transfer of technology to the end users is a complex task which consists of a number of components and dimensions. One of the important components is proper linkage between technology generating system and the client system. In this regard, innovative approaches like need assessment, participatory planning and implementation, and direct scientist-farmer interface facilitated faster dissemination of technologies and consequent adoption by the farmers/clients. Therefore, increasing access to quality seed at affordable prices would be a priority in order to significantly increase potato yields in the country. Thus, to satisfy the increasing demand for quality potato seed tubers in the country, it is highly recommended that the informal seed sector should be highly strengthened and its potential built until there is a well-established formal seed production system.

\section{ACKNOWLEDGEMENTS}

We are grateful to Mr. Tamiru Mihrete, Mr. Melaku Demissie and Mr. Tesfaye Amare for their technical support during the implementation of the activities. The work was funded by Ethiopian Institute of Agricultural Research (EIAR), International Potato Centre (CIP) and Potato and Sweet Potato Research Network of Eastern and Central Africa (PRAPACE).

\section{REFERENCES}

The Federal Democratic Republic of Ethiopia Central Statistical Agency (2014a). Ethiopian Agricultural Sample Survey Report of 2013/2014. Statistical Report on Farm Management Practices Private Peasant holdings, Meher season, Volume III. pp. 17-19. Addis Ababa, Ethiopia.

Badoni, A., \& Chauhan, J. S. (2010). Conventional vis-avis biotechnological methods of propagation in potato: A review. Stem Cell, 1(1), 1-6.

Batool, A., Syed S. H. Z., Muhammad, A., Ahsan, M. \& Muhammad, N. (2014). Effect of growth regulators in meristem culture of Potato (Solanum Tuberosmum L.). Science Technology and Development. 33(2), 80-84.

Berga L, Gebremedhin W., Terrissa J., Bereke-Tsehai T. (1994). Potato Agronomy Research. In: Edward Herath and Lemma Dessalegn (Eds.). In:
Proceedings of the Second National Horticultural Workshop of Ethiopia. Addis Ababa, 1-3 December 1992.Institute of Agricultural Research and Food and Agriculture Organization.

Berga L., \& G. W.giorgis (1994). Prospects of seed potato production in Ethiopia. In: Proceedings of the second national horticultural workshop of Ethiopia, ed. E. Hareth \& D. Lemma, 254-275. Addis Ababa: Institute of Agricultural Research and FAO.

Berrios, D.E. \& Rubirigi, A. (1993). Integrated control of bacterial wilt in seed production by the Burndi National potato program. In: Bacterial wilt. ACIAR proceedings No. 45. Hartman, G.L. \& Hayward, A.C (Eds), PP. 284-288. Canberra, Australia.

CSA (Central Statistical Agency), (2019/20). Agricultural Sample Survey, report on area and production of major crops of meher Season for private peasant holdings. Volume I, Statistical Bulletin 589. Addis Ababa, Ethiopia

CSA (Central statistical agency), (2015/16). Agricultural sample survey, report on area, production and farm management practice of belg season crops for private peasant holdings. Volume V, Statistical Bulletin 578. Addis Ababa, Ethiopia.

Central Statics Authority (CSA), (2014b). Ethiopian Agricultural Sample Survey Report of 2013/2014. Statistical Report on Farm Management Practices Private Peasant holdings, Belg season,5, 17-18. Addis Abeba, Ethiopia.

Central Statics Authority (CSA), (2009). Agricultural sample survey: Report on area and production of crops, Addis Abeba, Ethiopia, p.126.

Endale G., G. W. Giorgis \& B. Lemaga. (2008). Potato Seed Management. In: Root and Tuber Crops. The untapped Resources. Gebremedhin W/Giorgis, Endale Gebre and Berga Lemaga eds.). Pp53-78, EIAR, Addis Ababa.

FAOSTAT (2014) Production: Potatoes. Available at: http://faostat.fao.org/site/567/default.aspx\#

ancor, Food and Agriculture Organization of the United Nations, Rome, Italy.

FAO. (2010). Quality declared planting material: Protocols and standards for vegetatively propagated crops. FAO plant protection and production paper number 195 . Rome, Italy.

FAO. (2008). International Year of the Potato. CIP World Potato Atlas; FAOSTAT; World Potato Congress; 
Potatoes South Africa.

French, E.R. (1994). Strategies for integrated control of bacterial wilt of potatoes. In: Bacterial wilt; the disease and its causative agent, pseudomonas solanacearum. Hayward, A.C. and Hartman, G.L. (Eds.), 288pp. CAB International, UK.

Gebremedhin, W., A. Solomon, E. Gebre, A. Tesfaye, B. Kassa, D. Bekele, Y. Lemma \& K. Bedane. (2006). Transforming the traditional Agricultural system through Improved Technologies in the Center High lands of Ethiopia. Tsedeke Abate (eds.) 2006. In: Proceedings of Scaling up and scaling out development Technologies in Ethiopia. An International Conference 9-11 May 2006, Addis Ababa, Pp 159-168.

Gebremedhin, W/Giorgis, E. Gebre \& B. Lemaga. (2008). Potato Agronomy. In: Root and Tuber Crops. The untapped Resources. (Gebremedhin W/Giorgis, Endale Gebre and Berga Lemaga eds.). Pp 33-54, EIAR, Addis Ababa.

Gildemacher, P. R., Schulte-Geldermann, E., Borus, D., Demo, P., Kinyae, P., Mundia, P. \& Struik, P. C. (2011). Seed potato quality improvement through positive selection by smallholder farmers in Kenya. Potato Research, 54, 253-266.

Gildemacher, P. R., Kaguongo, W., Ortiz, O., Tesfaye, A., Woldegiorgis, G., Wagoire, W. W. \& Leeuwis, C. (2009). Improving potato production in Kenya, Uganda and Ethiopia: a system diagnosis. Potato research, 52(2), 173-205.

Haverkort, A. J., van Koesveld, M. J., Schepers, H. T. A. M., Wijnands, J. H. M., Wustman, R., \& Zhang, X. X. (2012). Potato prospects for Ethiopia: on the road to value addition (No. 528). Ppo Agv.

Hirpa, A., Meuwissen, M. P., Tesfaye, A., Lommen, W. J., Lansink, A. O., Tsegaye, A., \& Struik, P. C. (2010). Analysis of seed potato systems in Ethiopia. American Journal of Potato Research, 87(6), 537-552.

Kassanis, B. (2008). The use of tissue culture in producing virus-free clones from infected potato varieties. Annals of Applied Biology, 45(3), 422427.

Lemaga, B., Hakiza, J. J., Alacho, F. 0., \& Kakuhenzire, R. (1997). Integrated control of potato bacterial wilt in Southwestern Uganda. In Proceedings of the Fourth Triennial Congress of the African Potato Association, Pretoria, South Africa.
Low, J.W. (1997). Potato in south-west Uganda: Treats to sustainable production .African Crop Science journal, 5, 395-412.

Michieka, A.O. (1993). Screening CIP potato germplasm for resistance to Pseudomonas Solanaceram E. F. Smith. Proceedings of a workshop on bacterial wilt of potato caused by Pseudomonas Solanaceram, Bujumbura, Brundi. pp 27-31.

Mahamond, 0. (2006). Utilization of tissue culture techniques in a seed potato tuber production Schemes. Wageningen. Nethrlands. p.264.

Naik, P.S., Karihaloo J.L. (2008). Micro propagation for the production of quality potato seed in AsiaPacific. Asia-Pacific consortium on Agricultural biotech. New Delhi, India.p.47.

Nyunza, G., Mwakaje, A.E.G. (2012). Analysis of round potato marketing in Tanzania: The case of Rungwe district, Tanzania. International Journal of Business and Social Science, 3(23), 86 - 96.

Nyangeri, J.B, Gathuru, E.M. \& Mukunya, D.M. (1984). Effect of latent infection on the spread of bacterial wilt of potatoes in Kenya. Tropical pest management, 30, 163-165.

Rahman, M. S., Akanda, A. M., Mian, I. H., Bhuian, M. K. A., \& Karim, M. R. (2010). Growth and yield performance of different generations of seed potato as affected by PVY and PLRV. Bangladesh Journal of Agricultural Research, 35(1), 37-50.

Salazar, L. (1996). Potato viruses and their control International Potato Center (CIP), Lima.

Saumtally, S., Autrey, L.J.C., Ferre, P. \& Dookun, A. (1993). Disease management strategies for the Control of bacterial wilt disease of potato in Mauritius. In: Bacterial wilt. ACIAR proceedings No. 45. Hartman, G.L. and Hayward, A.C. (Eds.), PP 289293. Canberra, Australia.

Sengooba, T., Hakiza, J.J., Mukalazi, J.,Olanya, M., ElBedawy, R., Ewell, P., Lemaga, B., Adipala, E. (2001). An overview of opportunities and challenges to the management of late blight in tropical environments. In: Tenyaw. J.S, Nampala, P., tusime,G. and Osir, M.(Eds.) African Crop science Proceedings, 5, 395-398.

Shekhawat, G.S. (1995). Effect of changes in seed sources on potato bacterial wilt. In: Integrated Management of Bacterial wilt. Proceedings of an international workshop, 11-16 October, 1993. Hardy, B. and French, E.R. (Eds.), PP 79-86. New 
Delhi, India.
Tewodros, A., Paul C. S. \& Adane H. (2014).
Characterization of seed potato (Solanum
tuberosum L.) Storage, pre -planting treatment

and marketing systems in Ethiopia: the case of West-arsi zone. African journal of agricultural research, 9 (15), 1218-1226.

Publisher's note: EScience Press remains neutral with regard to jurisdictional claims in published maps and institutional affiliations.

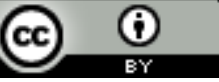

Open Access This article is licensed under a Creative Commons Attribution 4.0 International License, which permits use, sharing, adaptation, distribution and reproduction in any medium or format, as long as you give appropriate credit to the original author(s) and the source, provide a link to the Creative Commons license and indicate if changes were made. The images or other third-party material in this article are included in the article's Creative Commons license, unless indicated otherwise in a credit line to the material. If material is not included in the article's Creative Commons license and your intended use is not permitted by statutory regulation or exceeds the permitted use, you will need to obtain permission directly from the copyright holder. To view a copy of this license, visit http://creativecommons.org/licenses/by/4.0/.

(C) The Author(s) 2019. 